\title{
Rapid detection of Galba truncatula in water sources on pasture-land using loop-mediated isothermal amplification for control of trematode infections
}

\author{
Chelsea N. Davis ${ }^{1}$, Fiona Tyson ${ }^{1}$, David Cutress ${ }^{1}$, Emma Davies ${ }^{1}$, Dewi Llyr Jones ${ }^{1,2}$, Peter M. Brophy ${ }^{1}$, \\ Alex Prescott ${ }^{1}$, Michael T. Rose ${ }^{1,3}$, Manod Williams ${ }^{1}$, Hefin Wyn Williams ${ }^{1}$ and Rhys Aled Jones ${ }^{1 *}$ (D)
}

\begin{abstract}
Background: Fascioliasis caused by the trematodes Fasciola hepatica and F. gigantica, is a global neglected zoonotic disease estimated to cost the livestock industry over $€ 2.5$ billion annually. Farm management measures and sustainable use of anthelmintics can, in principle, effectively control trematode infection in livestock and reduce the rate of developing anthelmintic resistance. Previously, we designed an environmental DNA (eDNA) assay to identify a common trematode intermediate host, the freshwater snail Galba truncatula, in water sources to measure specific trematode infection risk areas on pasture-land. To improve this procedure, we now report a loop-mediated isothermal amplification (LAMP) assay to identify G. truncatula eDNA.
\end{abstract}

Methods: A LAMP assay was designed and optimised (e.g. temperature, time duration and primer concentration) to identify G. truncatula DNA. The ability of the LAMP assay to target G. truncatula DNA was identified, and LAMP assay limit of detection was investigated in comparison to conventional PCR. In the field, 48 water samples were collected from stream, ditch and water pool habitats in four locations at two Aberystwyth University farms over a seven week period to investigate the applicability of the LAMP assay for use on eDNA samples, in comparison to conventional PCR.

Results: The LAMP assay delivered detectable results in $30 \mathrm{~min}$ at $63^{\circ} \mathrm{C}$. The assay discriminated between $\mathrm{G}$. truncatula DNA and non-target DNA, presenting a level of DNA detection comparable to conventional PCR. No significant difference was found between the ability of the LAMP and PCR assay to identify G. truncatula eDNA in water samples. Kappa coefficient analysis revealed a moderate level of agreement between LAMP and PCR assays.

Conclusions: This study demonstrated that the LAMP assay can detect G. truncatula eDNA in a simple and rapid manner. The LAMP assay may become a valuable tool to determine optimum pasture management for trematode parasite control.

Keywords: Loop-mediated isothermal amplification, Environmental DNA, Farm management, Trematode, Fluke, Galba truncatula, Fasciola hepatica, Calicophoron daubneyi

*Correspondence: raj22@aber.ac.uk

${ }^{1}$ Institute of Biological, Environmental and Rural Sciences, Aberystwyth University, Aberystwyth, UK

Full list of author information is available at the end of the article

\section{Background}

Galba truncatula is an intermediate host for the trematodes Fasciola hepatica and Calicophoron daubneyi [1]. Trematode parasite stages develop and multiply via

c) The Author(s) 2020. This article is licensed under a Creative Commons Attribution 4.0 International License, which permits use, sharing, adaptation, distribution and reproduction in any medium or format, as long as you give appropriate credit to the original author(s) and the source, provide a link to the Creative Commons licence, and indicate if changes were made. The images or other third party material in this article are included in the article's Creative Commons licence, unless indicated otherwise in a credit line to the material. If material is not included in the article's Creative Commons licence and your intended use is not permitted by statutory regulation or exceeds the permitted use, you will need to obtain permission directly from the copyright holder. To view a copy of this licence, visit http://creativecommons.org/licenses/by/4.0/. The Creative Commons Public Domain Dedication waiver (http//creativecommons.org/publicdomain/zero/1.0/) applies to the data made available in this article, unless otherwise stated in a credit line to the data. 
polyembryony in G. truncatula to produce cercaria. These encyst on herbage as infective metacercaria, which consequently infect definitive hosts, such as ruminant species [2, 3]. Fasciola hepatica is a trematode of worldwide economic importance [4] as the disease it causes is estimated to cost the global livestock production industry $€ 2.5$ billion annually [5]. Furthermore, at least 2.4 million people are currently infected in over seventy countries, with millions more at risk of this food-borne disease [4]. In addition, $C$. daubneyi is an emerging trematode of concern in temperate countries [6-8]. In the absence of vaccines, trematode control in the definitive host is primarily via anthelmintic administration; however, anthelmintic resistance and the limited availability of novel anthelmintic compounds threatens sustainable control [9].

Farm management combined with the effective use of anthelmintics has been found to control the disease and prevent resistance $[10,11]$. Farm management practices that can reduce host parasite exposure include improving grazing management, draining pasture, fencing off wet pastures, using water troughs, and managing animal stocking rate [12-14]. Currently, regional liver fluke infection risk may be remotely forecasted using climatic models such as the Ollerenshaw index [15], whilst research is ongoing to develop geographical information system and satellite imagery analysis tools that aim to identify specific infection risk areas in fields [16-18]. However, even in areas where climatic and environmental conditions seem suitable, intermediate snail hosts may be absent leading to zero trematode infection risk for livestock grazing those areas $[12,19]$.

Recently, a water-based environmental DNA (eDNA) assay has been designed to identify the presence of $G$. truncatula in water sources on pasture-land [20]. An optimised G. truncatula eDNA assay would be cost-effective, simple and rapid to undertake, meaning this method would be ideal to implement localised and seasonal farm management practices on a per field basis. Loop-mediated isothermal amplification (LAMP) assays have been used to detect trematode species in field and laboratory settings [21]. LAMP assays are highly sensitive and easy to undertake, requiring only designed primers, DNA polymerase and a water bath or heat block to complete the reaction, and the results can be analysed visually [22-27]. LAMP assays are also highly specific as they exploit up to six primers for target amplification and are therefore less prone to non-target DNA issues than conventional PCR tests $[22,28,29]$. Consequently, a LAMP assay designed to detect the G. truncatula DNA in combination with a previously designed water-based eDNA assay, could be a valuable new tool to identify farm trematode infection risk areas on pasture-land.

\section{Methods \\ LAMP design}

A set of six LAMP PCR primers (Sigma-Aldrich, St. Louis, USA); a forward inner primer (FIP), a backward inner primer (BIP), two outer primers (F3 and B3) and two loop primers (LoopB and LoopF) were designed with assistance by Mast Group Ltd (Bootle, UK) to amplify G. truncatula DNA according to published G. truncatula internal transcribed spacer 2 (ITS2) sequences (GenBank: AJ296271.1, KT280448.1. KT781252.1, MH561919.1, JX536270.1; Table 1). The primers were aligned and checked for specificity to G. truncatula DNA using comparative genome Basic Local Alignment Search Tool (BLAST) analysis.

The final reaction mixture $(10 \mu \mathrm{l})$ contained $3 \mathrm{pmol}$ of outer primer (F3 and B3), $25 \mathrm{pmol}$ of inner primer (FIP and BIP) and 12 pmol of loop primer (loop B and loop F). MAST ISOPLEX ${ }^{\circledR}$ DNA Lyo kit (Mast Group Ltd) and $120 \mu \mathrm{M}$ hydroxy naphthol blue (HNB) were used to make the mastermix, before adding $0.8 \mu$ of primer mix and $1 \mu \mathrm{l}$ of DNA. Amplification was conducted at $63{ }^{\circ} \mathrm{C}$ for $30 \mathrm{~min}$ in a thermocycler (TC-4000, Techne, Stone, UK).

The LAMP reaction conditions were optimised with different parameters including assay temperature (60.4$64.7{ }^{\circ} \mathrm{C}$ ), primer concentration (between $22-28$ pmol for FIP and BIP; 10-14 pmol loop F and loop B; and 2.53.5 pmol F3 and B3) and incubation time (10-40 min) using triplicate biological replicates. Each LAMP assay run included a negative control (DNAase-free water only) and a positive control (genomic DNA extracted from G. truncatula snails). Samples were considered positive when the LAMP product showed a colour change from the violet-coloured negative control, to a sky-blue colour similar to the positive control, in addition to the presence or absence of banding after gel electrophoresis of LAMP product.

LAMP primer cross-reactivity was investigated by undertaking LAMP reactions using triplicate biological replicates of DNA extractions from the lymnaeid snails Radix balthica, Lymnaea fuscus, Omphiscola glabra,

Table 1 Primers targeting G. truncatula ITS2 DNA sequence used for LAMP assay

\begin{tabular}{lll}
\hline Primers & Sequence $\left(5^{\prime}-3^{\prime}\right)$ & $\begin{array}{l}\text { Amplicon } \\
\text { size }(\mathrm{bp})\end{array}$ \\
\hline F3 & CTCGGCGATGGTTGGATA & 18 \\
B3 & ATCTCGTCCGATCTGAGG & 18 \\
FIP & CCGAGAACGCCACGATAATTGTCCGTTCATCTCGTAAC & 28 \\
BIP & AGTCCATGGCATCGCAGCACCACGTAGCGTCTTAGA & 36 \\
LoopF & CTGCCTGGCGGTAGAGAA & 18 \\
LoopB & GTGGGTGGAGAACAAGGG & 18 \\
\hline
\end{tabular}


Stagnicola palustris and Lymnaea stagnalis. Lymnaea fuscus specimens were gifted by the National Museum Wales, O. glabra DNA extracts were gifted by the Royal Zoological Society of Scotland (RZSS) and L. stagnalis specimens were gifted by Aberystwyth University. Specimens of $R$. balthica and S. palustris were collected in the field after identification with a gastropod dichotomous key [30].

The lower limit of detection of the LAMP assay was determined by 10 -fold dilutions of a known concentration of G. truncatula genomic DNA extract. The last dilution where all three replicates were recorded positive was considered as the detection limit.

\section{DNA extraction and conventional PCR}

Genomic DNA from all snail species except O. glabra was extracted using an adaptation of a Chelex ${ }^{\circledR}$ (Bio-Rad, Hercules, USA) method [31], as previously described [32]. Omphiscola. glabra DNA extraction was undertaken at RSZZ using a blood and tissue kit (Qiagen, Hilden, Germany). Extracted DNA samples were stored at $-20{ }^{\circ} \mathrm{C}$ until use.

LAMP assay performance was compared against a conventional PCR method previously described [20]. Modifications to the original method included the total reaction volume, where a $10 \mu \mathrm{l}$ master mix was created containing $5 \mu$ l of Platinum ${ }^{\text {TM }}$ Green Hot Start PCR Master Mix (Thermo Fisher Scientific, Hayward, USA), $0.5 \mu \mathrm{l}$ of each $10 \mu \mathrm{M}$ primer, $1 \mu \mathrm{l}$ of the extracted DNA and nuclease-free water. A non-template control (DNAasefree water) as a negative control and a positive control (genomic DNA extracted from G. truncatula snails) were included for each PCR run. The LAMP and PCR products $(10 \mu \mathrm{l})$ were analysed by $2 \%$ agarose gel (agarose: Bioline, Tris Acetate-EDTA buffer: National Diagnostics) electrophoresis (Midi Plus Horizontal Gel System, Fisherbrand, Hampton, USA) stained with SYBR safe DNA gel stain (Invitrogen, Carlsbad, USA) and observed under UV transillumination (Genoplex, VWR, Radnor, USA) or Typhoon FLA 9000 Gel Imaging Scanner (GE Healthcare, Chicago, USA).

The lower limit of detection of the conventional PCR was determined by 10 -fold dilutions of a known concentration of G. truncatula genomic DNA extract. The last dilution with all triplicate replicates testing positive was considered as the detection limit.

\section{eDNA collection and extraction}

To investigate the LAMP assay's capabilities of identifying the presence of G. truncatula on pasture-land, water samples were collected and analysed from four locations at Farm A $(52.424226 \mathrm{~N},-4.051630 \mathrm{~W})$ and Farm B $(52.425258 \mathrm{~N},-4.029358 \mathrm{~W})$ which are both located at Aberystwyth University, Ceredigion, Wales, UK, over a seven-week period (3rd March-13th June 2019). In each sampling location, two replicate samples were collected at six time points in this period, giving a total of 48 samples. Each sampling location were in G. truncatula habitats enrolled in a long-term eDNA research project. Sampling location types included two slow moving streams, a boggy area containing standing water pools and a drainage ditch (Fig. 1).

A filter-based eDNA capture protocol was used throughout this study following the methodology of Jones et al. [20]. A blank control (500 ml distilled water) was undertaken during every day of eDNA collection. Filters were stored at $-20{ }^{\circ} \mathrm{C}$ until use. Non-disposable equipment were soaked in $7 \%$ sodium hypochlorite overnight, before being rinsed in water and dried to avoid cross-contamination between sample collections [33].

DNA was extracted from filter samples using the DNeasy ${ }^{\circledR}$ PowerSoil ${ }^{\circledR}$ kit (Qiagen). Each filter, including blank controls, was homogenised using a sterile pipette tip and the whole filter was then subjected to DNA extraction via the PowerSoil ${ }^{\circledR}$ kit protocol. Each eDNA sample was tested in triplicate by both LAMP and PCR assays, where the sample was deemed positive if one or more of the triplicate technical replicates gave a positive result.

\section{Statistical analysis}

The success of the newly developed LAMP assay in detecting G. truncatula DNA in extracted eDNA samples compared to PCR was analysed statistically using a generalized logistic regression mixed model in SPSS (v.25). The subject variable was each eDNA sample, with DNA amplification method (LAMP or PCR) the within subject variable. The dependent variable was the outcome of each DNA amplification test (positive or negative). The DNA amplification method (LAMP or PCR) was inserted as a fixed factor in the model to identify if any differences in DNA amplification from each sample was seen between both methods. The habitat and sampling timepoint were inserted into the model as random factors to identify if any differences in test performance was influenced by sampling location and period. Outcomes were deemed significant if $P<0.05$. Kappa coefficient analysis with $95 \%$ confidence level was undertaken to assess the agreement between LAMP and PCR assays in amplifying eDNA using SPSS (v.25).

\section{Results}

Comparison of LAMP and conventional PCR limit of detection

To determine the limit of detection of the LAMP assay, 10 -fold dilutions $\left(10^{1}-10^{9}\right)$ of a known concentration 


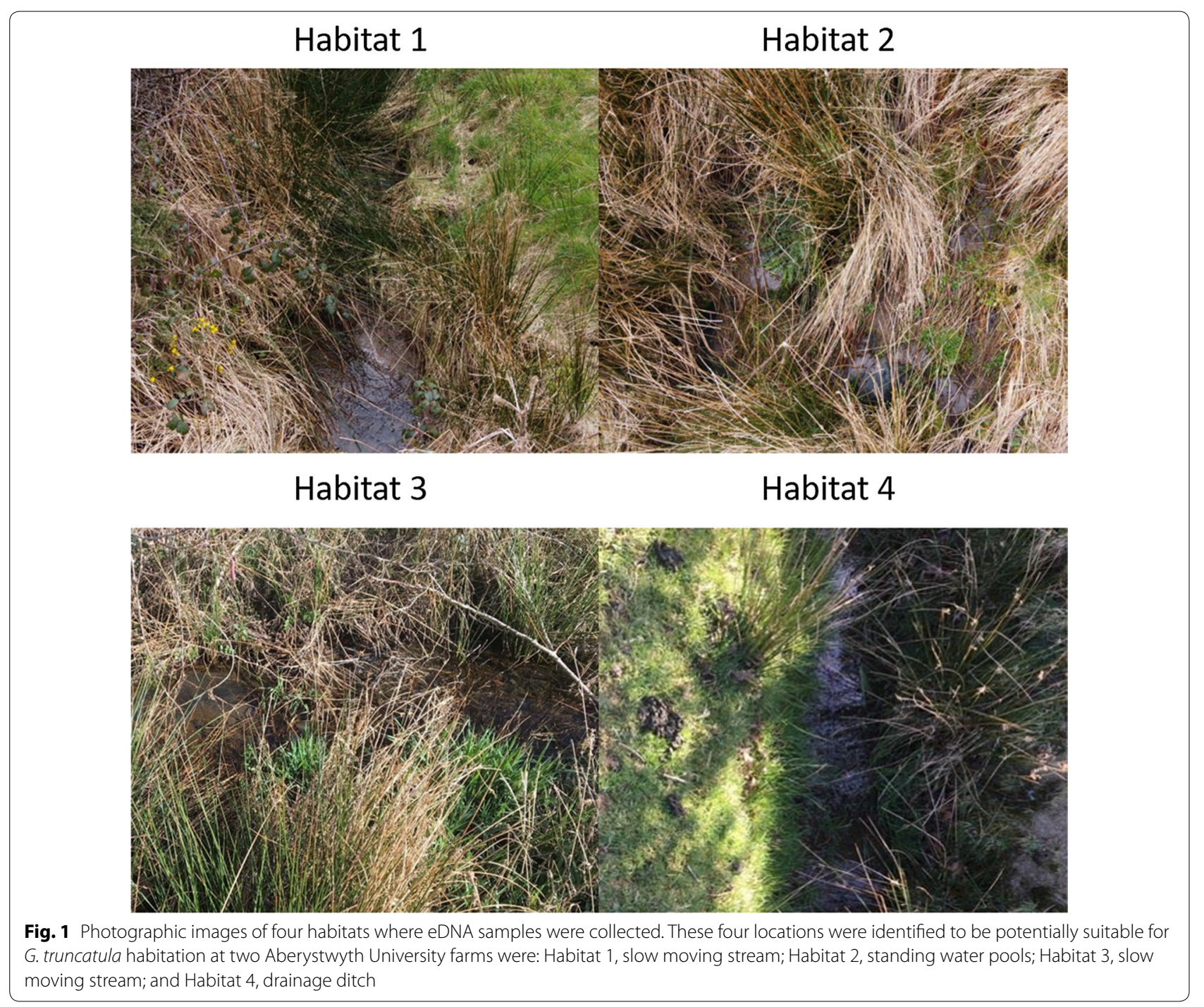

of G. truncatula genomic DNA extract and a range of primer concentrations were used for LAMP experiments. The lower limit of detection for the LAMP assay was found to be $10^{5}$-fold dilution $(0.349 \mathrm{pg} / \mu \mathrm{l})$ when using 22-28 pmol FIP and BIP primer, 10-14 pmol loop F and loop B primer and 2.5-3.5 pmol F3 and B3 primer in the reaction (Fig. 2).

Similar 10-fold dilutions were used to compare the limit of detection of the LAMP assay with conventional PCR. PCR was identified as having a similar lower limit detection $\left(10^{5}\right.$-fold dilution, e.g. $\left.0.5 \mathrm{pg} / \mu \mathrm{l}\right)$ compared to the LAMP assay in these conditions (Fig. 3).

\section{LAMP temperature optimisation}

All reaction temperatures $\left(60.4-64.7{ }^{\circ} \mathrm{C}\right)$ investigated amplified G. truncatula genomic DNA during temperature optimisation of the LAMP assay (Fig. 4). As the MAST ISOPLEX ${ }^{\circledR}$ DNA Lyo kit recommends undertaking LAMP assays at $63{ }^{\circ} \mathrm{C}$, this temperature was chosen for further experimentation.

\section{LAMP reaction duration optimisation}

To determine the time duration in which the LAMP assay identified a positive outcome, 10 -fold dilutions $\left(10^{4}-10^{6}\right)$ of G. truncatula genomic DNA extract were subjected to the LAMP assay for four time durations $(10,20,30$ and $40 \mathrm{~min}$ ) (Fig 5). The LAMP assay showed a positive result in $20 \mathrm{~min}$ at $10^{4}$ fold dilution of G. truncatula genomic DNA extract (e.g. $3.49 \mathrm{pg} / \mu \mathrm{l}$ ), although this time duration reduced the limit of detection of the LAMP assay by 10-fold. A time duration of $30 \mathrm{~min}$ resulted in a positive outcome at the lower limit of detection for the LAMP 


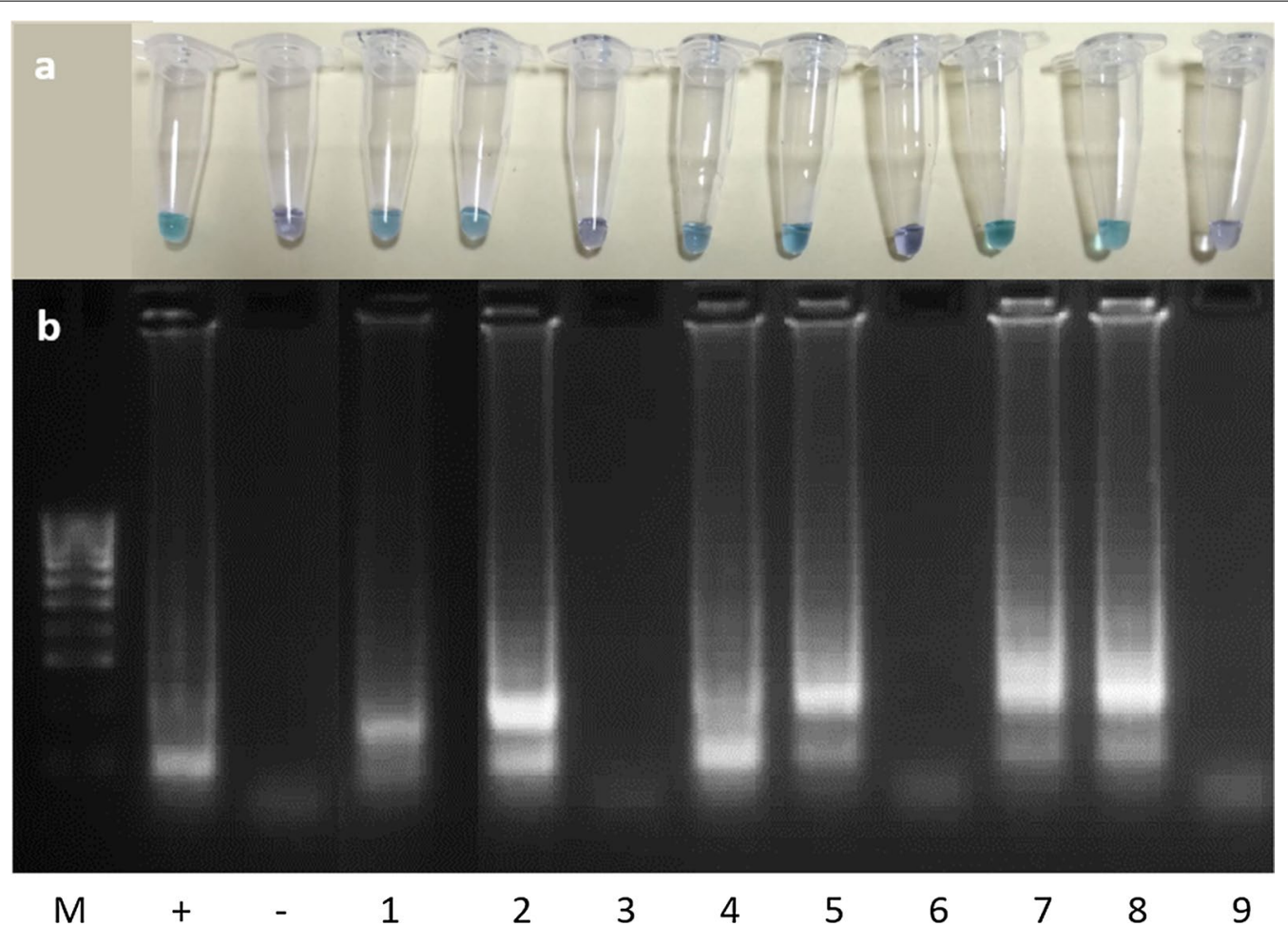

Fig. 2 Lower limit detection and optimum primer concentration of G. truncatula LAMP assay. This was determined by undertaking (a) LAMP assay and (b) confirmation of results of the LAMP assay products using agarose gel (2\%) electrophoresis. Lane M: 100 bp DNA Ladder (Thermo Fisher Scientific). Lane + (positive control of $34.9 \mathrm{ng} / \mathrm{\mu l}$ G. tuncatula genomic DNA extract) and Lane- (negative control) were both undertaken at primer concentration 3 pmol of F3 and B3 primer, 25 pmol of FIP and BIP primer and 12 pmol loop B and loop F primer. Lane 1 (10 dilution of G. tuncatula genomic DNA extract), Lane 2 ( $10^{5}$ dilution of $G$. tuncatula genomic DNA extract) and Lane 3 ( $10^{6}$ dilution of G. tuncatula genomic DNA extract) were undertaken at primer concentration 2.5 pmol of F3 and B3 primer, 22 pmol of FIP and BIP primer and 10 pmol of loop B and loop F primer. Lane 4 ( $10^{4}$ dilution of $G$. tuncatula genomic DNA extract), Lane 5 ( $10^{5}$ dilution of $G$. tuncatula genomic DNA extract) and Lane 6 ( $10^{6}$ dilution of $G$. tuncatula genomic DNA extract) were undertaken at primer concentration 3 pmol of F3 and B3 primer, 25 pmol of FIP and BIP primer and 12 pmol of loop B and loop F primer. Lane 7 ( $10^{4}$ dilution of G. tuncatula genomic DNA extract), Lane 8 (10 $0^{5}$ dilution of $G$. tuncatula genomic DNA extract) and Lane 9 ( $10^{6}$ dilution of $G$. tuncatula genomic DNA extract) were undertaken at primer concentration 3.5 pmol of F3 and B3 primer, 28 pmol of FIP and BIP primer and 14 pmol of loop B and loop F primer

assay $\left(10^{5}\right.$-fold dilution $\left.=0.349 \mathrm{pg} / \mu \mathrm{l}\right)$, so was chosen as the optimum LAMP assay time duration.

\section{LAMP primer cross-reactivity}

Cross reactivity of the designed LAMP primers was investigated by undertaking the LAMP assay with genomic DNA of five snail species belonging to the family Lymnaeidae: S. palustris, O. glabra, L. stagnalis, $L$. fuscus and $R$. balthica which are closely related to and live in similar environments to G. truncatula. None of these snail species showed a positive result when the LAMP assay was undertaken, demonstrating that the designed LAMP primers showed the ability to discriminate between G. truncatula DNA and non-target snail DNA (Fig. 6).

\section{Detection of $G$. truncatula eDNA in water sources using the LAMP assay}

Water samples from pasture fields were used to test the applicability of the LAMP assay to identify G. truncatula DNA in the environment in comparison to PCR (Table 2). Both assays reported similar results, where samples taken from Farm A showed $17 / 24$ and $16 / 24$ positive results for G. truncatula DNA using the LAMP and PCR assay, respectively. At Farm B, 10/24 and 11/24 positive results for G. truncatula DNA were found using the LAMP and PCR assay, respectively.

There was no significant difference between the ability of the LAMP and PCR assays to identify the presence of G. truncatula eDNA in environmental samples $(P=1.000)$ (Table 3) with no significant random effect of habitat 


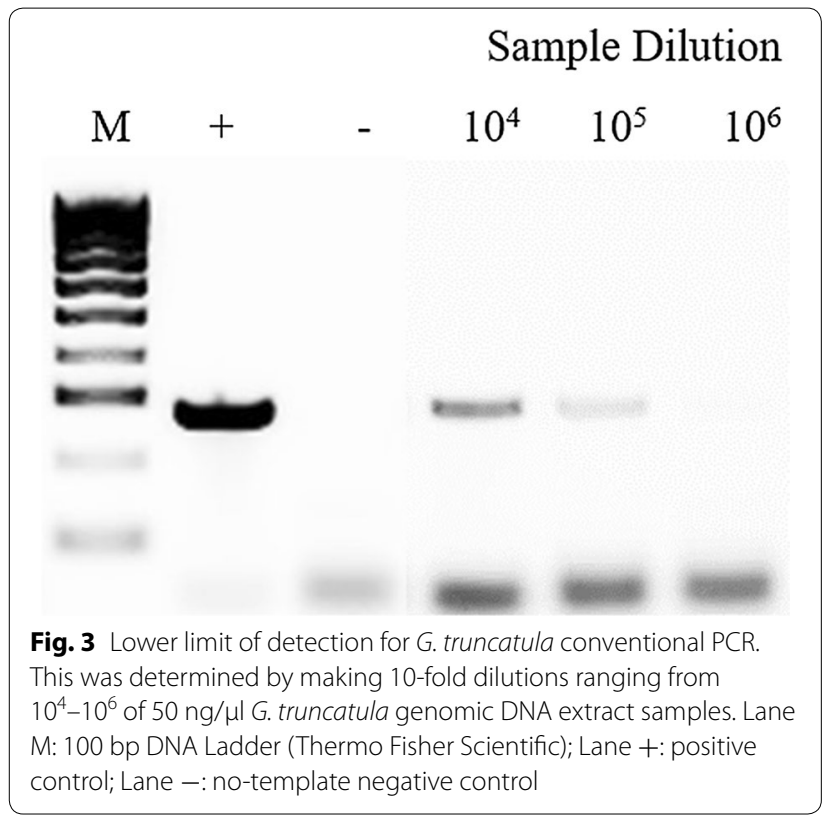

$(P=0.409)$ and sampling time $(P=0.222)$ on the results. Kappa coefficient analysis (Table 4) revealed a moderate level of agreement $($ Kappa $=0.577)$ between assays [34].

\section{Discussion}

The success of host trematode parasite transmission is heavily influenced by G. truncatula population dynamics in the environment [3]. Current methods for identifying precise trematode infection risk areas in fields by physically detecting G. truncatula presence are labourintensive, require expertise, and are time-consuming and costly $[12,19]$. In this paper, a practical LAMP assay has been designed to detect the eDNA of trematode intermediate host, G. truncatula, in water samples. Detection of G. truncatula eDNA may indicate trematode infection risk areas on pasture which will allow farm management practices to be applied to reduce trematode infection risk in livestock grazing specific pastures.

The limit of detection of the LAMP assay $(0.349 \mathrm{pg} /$ $\mu \mathrm{l})$ was comparable to conventional PCR $(0.5 \mathrm{pg} / \mu \mathrm{l})$, when using G. truncatula DNA extract in the reaction.

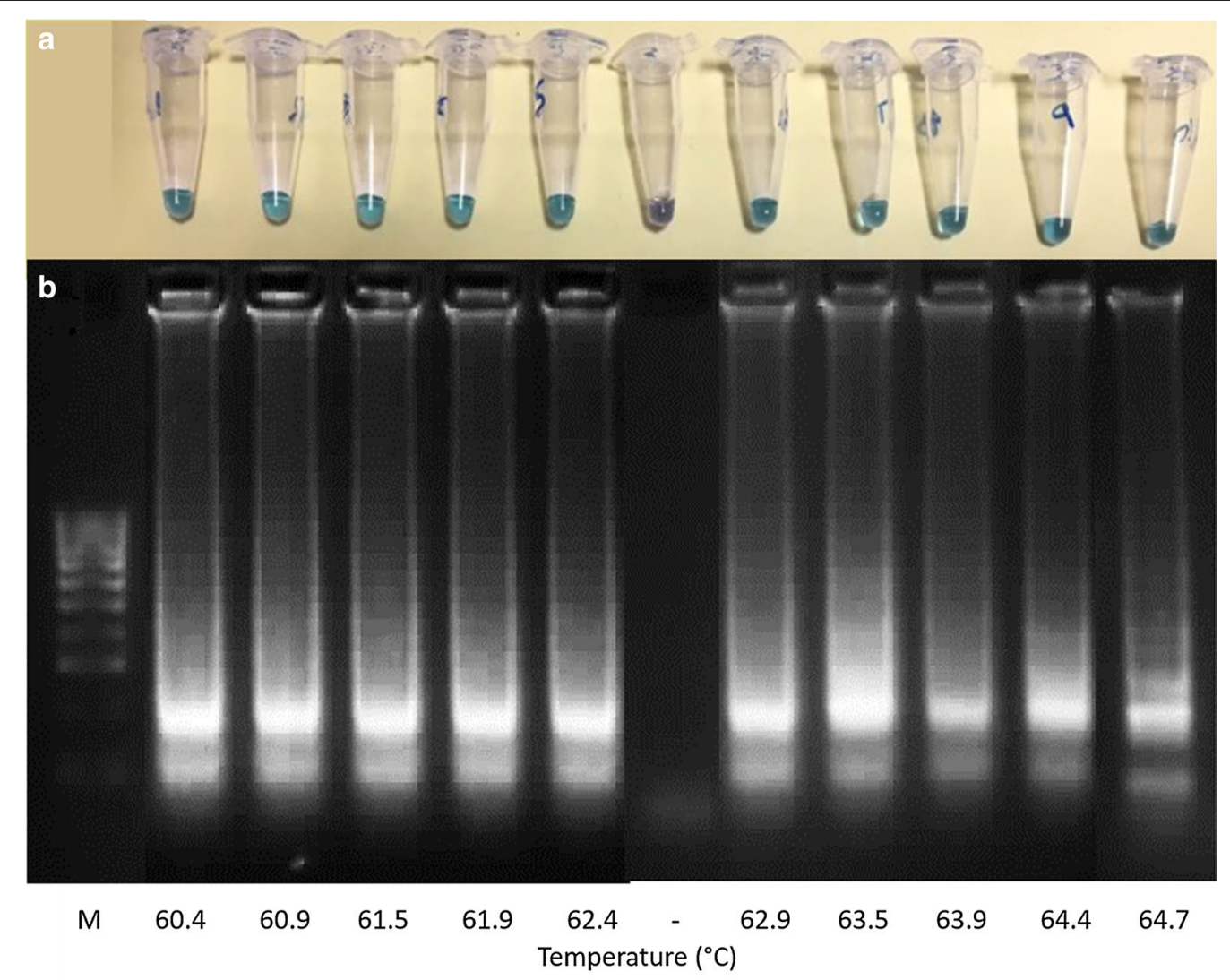

Fig. 4 Temperature optimisation of G. truncatula LAMP assay. This was determined by undertaking a LAMP assay (a) and confirmation of results of the LAMP assay products using agarose gel (2\%) electrophoresis (b). Temperatures ranged between $60.4-64.7^{\circ} \mathrm{C}$ of $34.9 \mathrm{ng} / \mu \mathrm{l} \mathrm{G}$. truncatula genomic DNA extract sample concentration. Lane M: 100 bp DNA Ladder (Thermo Fisher Scientific); Lane -: no-template negative control at $63^{\circ} \mathrm{C}$ 


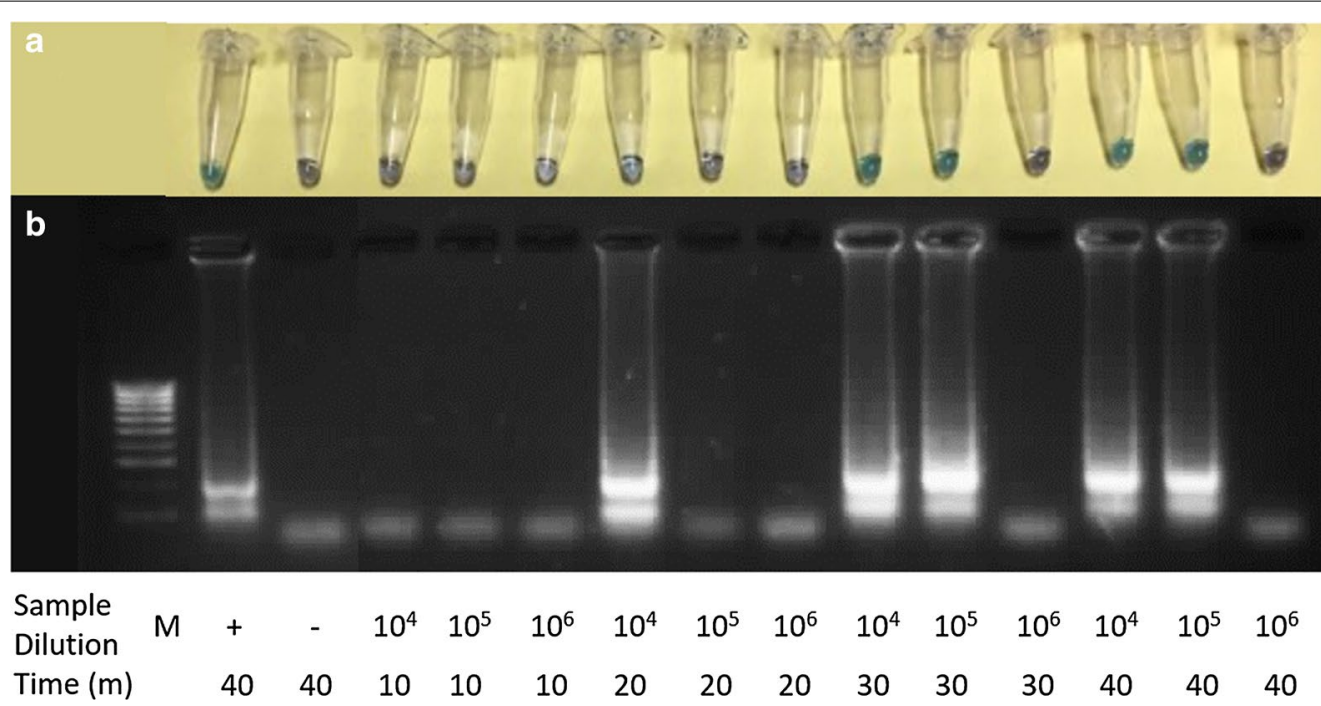

Fig. 5 Optimum time duration of G. truncatula LAMP assay. This was determined by undertaking a LAMP assay (a) and confirmation of results of the LAMP assay products using agarose gel (2\%) electrophoresis (b). Time durations ranged from 10-40 min and 10-fold dilutions ranged from 104-10 of $34.9 \mathrm{ng} / \mathrm{\mu l}$ G. truncatula genomic DNA extract sample concentration. Lane M: 100 bp DNA Ladder (Thermo Fisher Scientific); Lane +: G. truncatula positive control; Lane-: no-template negative control

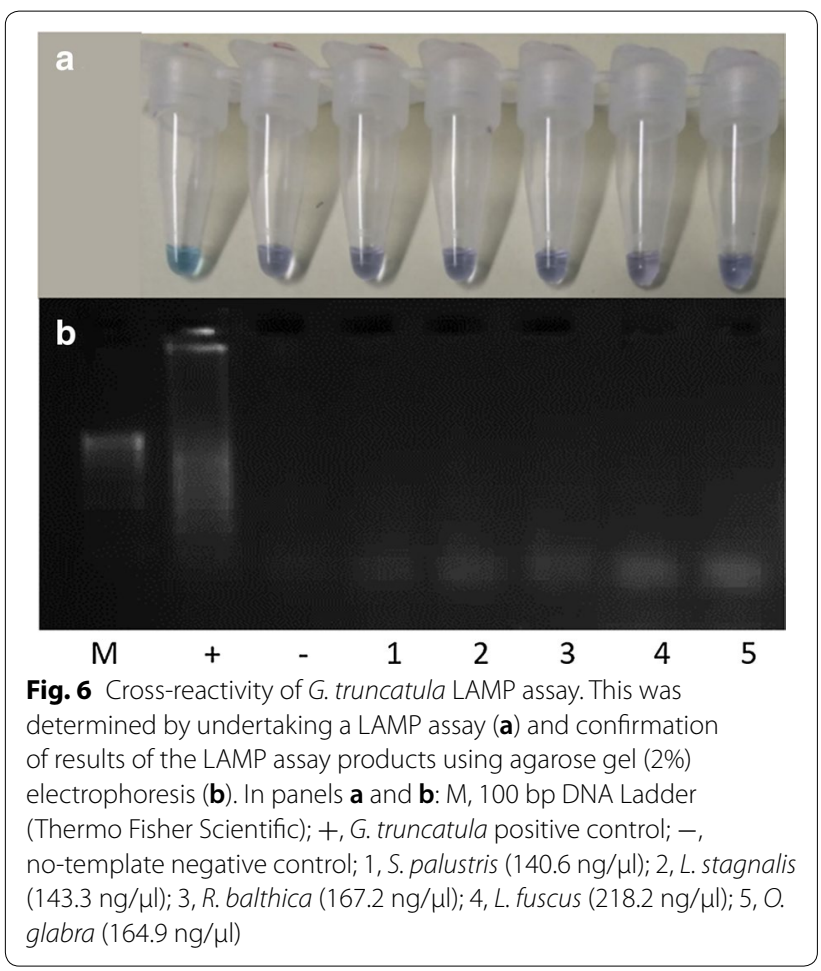

Similar results were found developing a LAMP assay to detect $O$. viverrini in human faeces where the limit of detection for the reaction was between $1 \mathrm{pg}$ and $100 \mathrm{fg}$ of template, although the LAMP assay limit of detection was 100-fold greater, compared to conventional PCR
[35]. In agreement with the present study, LAMP assays designed to detect Fasciola spp. in the faeces of sheep, $O$. viverrini in human faecal stools and Amphimerus spp. in human faeces showed the same 10-fold limit of detection as conventional PCR [36-38]. In contrast, investigations have found different outcomes upon LAMP assay DNA detection limits and adverse results when LAMP assays are compared to conventional PCR [39-41]. These inconsistent assay outcomes are likely due to the quality of the LAMP assay being dependent upon the regions that the primers were designed [22]. In this study, the ITS2 gene was chosen as the target gene for LAMP assay design, because the ITS2 sequence is known to occur in tandem repeats in the ribosomal DNA; it is therefore likely to be present in larger quantities in the environment $[42,43]$.

It is recognised that qPCR assays have lower detection limits than PCR assays [44]. Optimisation of a qPCR assay upon the detection of $F$. hepatica and A. tomentosa in water samples determined a limit of detection of $14 \mathrm{fg}$ or $50 \mathrm{fg}$, respectively, where the DNA detection limit was 100-fold greater than conventional PCR [45]. Compared to LAMP assay, qPCR is less practical to undertake due to the requirement of a precise, expensive instrument for amplification and a skilful labourer needed for detection of the amplified products [22].

All the reaction temperatures $\left(60.4-64.7^{\circ} \mathrm{C}\right)$ investigated amplified G. truncatula genomic DNA when optimising the LAMP assay, so $63{ }^{\circ} \mathrm{C}$ was chosen for further experimentation as recommended by the LAMP kit used. LAMP assays are most efficient at 
Table 2 Comparison of G. truncatula LAMP and PCR assays using environmental water samples

\begin{tabular}{|c|c|c|c|}
\hline Date collected & Habitat & $\operatorname{LAMP}(n / N)$ & $\operatorname{PCR}(n / N)$ \\
\hline \multicolumn{4}{|l|}{ Farm A } \\
\hline 03/05/2019 & 1 & $2 / 2$ & $0 / 2$ \\
\hline 03/05/2019 & 2 & $0 / 2$ & $0 / 2$ \\
\hline 09/05/2019 & 1 & $1 / 2$ & $1 / 2$ \\
\hline 09/05/2019 & 2 & $1 / 2$ & $1 / 2$ \\
\hline $16 / 05 / 2019$ & 1 & $1 / 2$ & $1 / 2$ \\
\hline $16 / 05 / 2019$ & 2 & $2 / 2$ & $2 / 2$ \\
\hline $30 / 05 / 2019$ & 1 & $2 / 2$ & $2 / 2$ \\
\hline $30 / 05 / 2019$ & 2 & $2 / 2$ & $2 / 2$ \\
\hline 06/06/2019 & 1 & $2 / 2$ & $2 / 2$ \\
\hline 06/06/2019 & 2 & $1 / 2$ & $1 / 2$ \\
\hline 13/06/2019 & 1 & $2 / 2$ & $2 / 2$ \\
\hline 13/06/2019 & 2 & $1 / 2$ & $2 / 2$ \\
\hline \multicolumn{4}{|l|}{ Farm B } \\
\hline 03/05/2019 & 3 & $1 / 2$ & $0 / 2$ \\
\hline 03/05/2019 & 4 & $0 / 2$ & $0 / 2$ \\
\hline 09/05/2019 & 3 & $0 / 2$ & $1 / 2$ \\
\hline 09/05/2019 & 4 & $0 / 2$ & $1 / 2$ \\
\hline $16 / 05 / 2019$ & 3 & $1 / 2$ & $2 / 2$ \\
\hline $16 / 05 / 2019$ & 4 & $1 / 2$ & $1 / 2$ \\
\hline $30 / 05 / 2019$ & 3 & $1 / 2$ & $1 / 2$ \\
\hline $30 / 05 / 2019$ & 4 & $2 / 2$ & $1 / 2$ \\
\hline 06/06/2019 & 3 & $1 / 2$ & $0 / 2$ \\
\hline 06/06/2019 & 4 & $0 / 2$ & $1 / 2$ \\
\hline 13/06/2019 & 3 & $2 / 2$ & $2 / 2$ \\
\hline $13 / 06 / 2019$ & 4 & $1 / 2$ & $1 / 2$ \\
\hline
\end{tabular}

Notes: eDNA samples were collected in four locations at Farm A and Farm B over a 7-week period. Area characteristics of the habitats were: 1, stream; 2 , water pools; 3, stream; 4, ditch (as shown in Fig. 1)

Abbreviation: $\mathrm{n} / \mathrm{N}$, positive/examined

these temperatures because they allow best performance of Bst DNA polymerase and double-stranded DNAs are at dynamic equilibrium around this temperature, so one of the LAMP primers (FIP) can anneal to the DNAs without a denaturing step to initiate synthesis $[22,24]$. The fact that the LAMP assay reaction can be undertaken under isothermal conditions using inexpensive equipment, means that detection of trematode infection risk areas on pasture-land can be conducted in less advanced field laboratories without the expense of thermocyclers and electrophoresis instrumentation.

LAMP assay results can be visualised in $30 \mathrm{~min}$ to detect G. truncatula genomic DNA extract at the limit of detection. Comparatively, the conventional PCR reaction took a further two hours to complete than the LAMP assay, and required gel electrophoresis to determine an outcome. A LAMP assay designed to detect $F$. hepatica and F. gigantica using four species-specific primers, took $45 \mathrm{~min}$ to obtain amplification and observe a visual result [26]. The addition of loop primers accelerates the LAMP reaction, as they hybridize to the stem loops, except for the loops that are hybridized by the inner primer, priming strand replacement DNA synthesis [28]. Using six primers, a LAMP assay designed to detect Schistosoma mansoni obtained positive results in $20 \mathrm{~min}, 30 \mathrm{~min}$ and $50 \mathrm{~min}$ when using $1 \mathrm{ng}, 1 \mathrm{pg}$ or $1 \mathrm{fg}$ DNA template, respectively [46]. The ability of a LAMP assay reaction to visualise an immediate result in $30 \mathrm{~min}$, presents a practical tool to quickly and effectively make decisions upon management of pasture-land. However, advancements are needed to develop a rapid field-based eDNA extraction method to fully capitalise on the capabilities of LAMP assay.

The LAMP primers showed the ability to discriminate between G. truncatula DNA and non-target DNA, as five closely related snails that live in similar environments to G. truncatula tested negative using the LAMP assay. Amplification of non-target DNA present in the sample is unlikely in LAMP assays due to at least six distinct regions on the DNA target being recognised by at least four primers in the reaction $[22,28]$. This suggests that the LAMP assay is robust enough to detect G. truncatula eDNA in areas where other snails co-occur.

The LAMP assay identified the presence of G. truncatula DNA in environmental samples (e.g. Farm A: 17/24, Farm B: 10/24 positive results) with no significant

Table 3 Generalized logistic regression mixed model comparing eDNA G. truncatula LAMP and PCR assays

\begin{tabular}{llll}
\hline Variable & $\beta$ & SE & $P$-value \\
\hline Intercept & -0.296 & 0.815 & 0.717 \\
LAMP assay & 0.000 & 0.444 & 1.000 \\
\hline Random effects & Variance & & \\
\hline Intercept & 4.074 & 0.516 & 0.409 \\
Habitat & 0.426 & 0.945 & 0.222 \\
Time & 1.155 &
\end{tabular}

Abbreviation: SE, standard error 
Table 4 Kappa agreement comparing eDNA G. truncatula LAMP and PCR assays

\begin{tabular}{lllll}
\hline No. of samples & & & \\
\hline PCR results & LAMP positive & LAMP negative & Total & Kappa value \\
\hline Positive & 16 & 5 & 21 & 0.577 \\
Negative & 5 & 22 & 27 & \\
Total & 21 & 27 & 48 & \\
\hline
\end{tabular}

Notes: The Kappa coefficient was undertaken with $95 \%$ confidence level and conducted using SPSS (v.25). The standard error $=0.119$ and $P<0.001$

difference to conventional PCR G. truncatula eDNA identification (e.g. Farm A: 16/24, Farm B: 11/24 positive results). Even though both farms showed similar positive results using both assays, three samples at Farm A and seven samples from Farm B showed conflicting results at different sampling points and habitat locations. This explains why the Kappa coefficient analysis showed a moderate level of agreement between LAMP and PCR assays. Similarities between PCR and LAMP assay results have also been reported detecting schistosome-infected snails, whereby 3/90 Biomphalaria pfeifferi were found infected with $S$. mansoni using both PCR and LAMP assays in field habitat locations, and 54/103 and 50/103 Bulinus spp. snails were found infected with $S$. mansoni using both PCR and LAMP assays, respectively [47]. In contrast, conventional PCR underestimated the presence of $C$. sinensis in snail, fish and shrimp species collected in 11/106 samples compared to LAMP, where the Kappa statistic showed the techniques had high consistency [48].

Environmental samples are known to be rich in PCR inhibitors (e.g. humic acids, potassium dichromate, formaldehyde and phenols) which can interfere with the PCR amplification [49]. Inhibition of PCR reactions by substances present in environmental samples is particularly important in low concentration samples and surface water samples [50]. LAMP assays have been found to be less affected by non-target DNA in comparison to PCR $[22,29]$. This is due to the Bst DNA polymerase used in LAMP amplification having activity at high temperatures which reduces non-specific priming and that Bst DNA polymerase is more resistant to inhibitors compared to other DNA polymerases [51]. In the present study, inhibitors present in the environmental water samples may have adversely affected the LAMP and PCR assay efficiencies, explaining the Kappa coefficient analysis outcome. Of note, the HNB dye used to visualise the present assay, does not interfere with DNA synthesis by Bst DNA polymerase [25]. One of the disadvantages of LAMP is the impracticality of including an internal positive control within each reaction [52]. However, it may be feasible to analyse spiked samples to identify if negative LAMP assays were inhibited [53]. Additionally, it is suggested that further research be conducted to understand to what extent PCR inhibitors associated with confounding factors (e.g. water turbidity and soil type) may affect this LAMP assay.

Because LAMP assays are less affected by non-target DNA, some studies have omitted DNA extraction steps, prior to conducting LAMP reactions [29, 54]. Rapidly heating urine samples in comparison to using urine DNA extraction mini kit or sodium hydroxide/sodium dodecyl sulfate extraction method, provided best results for extracting Schistosoma haematobium DNA detectable by the LAMP assay, where the limit of detection was 10-fold higher than when using the commercial kit [55]. Heating samples prior to undertaking LAMP assays has also been applied to blood samples to detect malaria $[51,56]$ and swaps to diagnose leishmaniasis [57] and trichomoniasis [58]. An eDNA LAMP assay which does not require complex DNA extraction steps, would enhance its value to be used as a routine farm management tool. Therefore, further research should investigate alternative methodology to concentrate water eDNA samples and extract DNA, to improve the practicality of the current LAMP assay.

The LAMP assay developed in this study detects the presence of the trematode intermediate snail host $G$. truncatula in the environment. The eDNA capture and extraction protocol utilised in this study has previously demonstrated a capability of identifying $F$. hepatica and C. daubneyi eDNA when used in conjunction with PCR [20]. LAMP assays have been developed to amplify $F$. hepatica DNA [26] and could be incorporated into this protocol to identify the presence of $F$. hepatica in the grazing environment. However, as the eDNA of infective and non-infective $F$. hepatica stages cannot be differentiated, interpreting $F$. hepatica eDNA detection in relation to infection risk would be challenging [20].

To further enhance the practicability of the LAMP assay as a farm management tool, a simple formulated ready-to-use LAMP kit should be made available [59]. A high throughput portable LAMP detection system has already been achieved for the diagnosis of malaria parasites, where DNA extraction to result visualisation can be undertaken within two hours without the need of pipetting and centrifugation [60]. Also, a point-of-care pathogen screening tool has been designed where sample acquisition, preparation, amplification and detection can be undertaken in one disposable tube in a field environment [61]. In the future, the current LAMP assay should be developed to provide real time results for multiple field locations on a farm, so farm management decisions can be promptly made to prevent livestock grazing trematode risk areas. 


\section{Conclusions}

This LAMP assay has the ability to detect G. truncatula DNA from water sources in the environment. Due to the short reaction time and ability to visualise results immediately using inexpensive equipment, we predict this LAMP assay will be a valuable new tool to rapidly and effectively make decisions to support farm management practices in trematode risk areas, specifically in individual field locations.

\section{Acknowledgements}

We would like to thank Ben Rowson and Harry Powell at the National Museum Wales for gifting L. fuscus specimens, Jenny Kaden and Alexander Ball at the Royal Zoological Society of Scotland for gifting O. glabra DNA extracts and Sarah Dalesman at Aberystwyth University for gifting L. stagnalis specimens to contribute towards the paper. We would also like to thank the Aberystwyth University farm staff for allowing access to farm locations during sample collection. IBERS receives strategic funding from BBSRC.

\section{Authors' contributions}

HWW and RAJ conceived and designed the study. CND, FT, ED and DC collected, processed and analysed the samples. CND, AP and RAJ developed the assay and analysed the data. HWW and RAJ contributed to the manuscript written first by CND. PMB, MTR, FT, DC, ED, DLJ and MW critically reviewed the manuscript. All authors read and approved the final manuscript.

\section{Funding}

This study was part of the PreciseAg (Precision Livestock Farming For A Sustainable Welsh Agricultural Industry) project funded by Higher Education Funding Council for Wales (HEFCW; Enhancing HE-FE Collaboration in Innovation and Engagement Activity 2017-18). The funding body had no role in the design of the study and collection, analysis, and interpretation of data and in writing the manuscript.

\section{Availability of data and materials}

All data generated or analysed during this study are included in this published article.

\section{Ethics approval and consent to participate}

Not applicable.

\section{Consent for publication}

Not applicable.

\section{Competing interests}

The authors declare that they have no competing interests.

\begin{abstract}
Author details
${ }^{1}$ Institute of Biological, Environmental and Rural Sciences, Aberystwyth University, Aberystwyth, UK. ${ }^{2}$ Coleg Cambria, Llysfasi, Ruthin Road, Ruthin, Denbighshire, UK. ${ }^{3}$ Tasmanian Institute of Agriculture, University of Tasmania, Sandy Bay, TAS, Australia.
\end{abstract}

Received: 22 May 2020 Accepted: 20 September 2020

Published online: 30 September 2020

\section{References}

1. Jones RA, Williams HW, Dalesman S, Brophy PM. Confirmation of Galba truncatula as an intermediate host snail for Calicophoron daubneyi in Great Britain, with evidence of alternative snail species hosting Fasciola hepatica. Parasit Vectors. 2015;8:656.

2. Gunn A, Pitt SJ. Parasitology: an integrated approach. West Sussex: Wiley; 2012.

3. Young ND, Hall RS, Jex AR, Cantacessi C, Gasser RB. Elucidating the transcriptome of Fasciola hepatica - a key to fundamental and biotechnological discoveries for a neglected parasite. Biotechnol Adv. 2010;28:222-31.
4. WHO. Fascioliasis; Geneva: World Health Organization; 2015. http://www. who.int/foodborne_trematode_infections/fascioliasis/en/

5. European Comission. A decade of EU-funded Animal Health; 2012.

6. Sanabria REF, Romero JR. Review and update of paramphistomosis. Helminthologia. 2008:45:64-8.

7. Malrait K, Verschave S, Skuce P, Van Loo H, Vercruysse J, Charlier J. Novel insights into the pathogenic importance, diagnosis and treatment of the rumen fluke (Calicophoron daubneyi) in cattle. Vet Parasitol. 2015;207:134-9.

8. Jones RA, Brophy PM, Mitchell ES, Williams HW. Rumen fluke (Calicophoron daubneyi) on Welsh farms: Prevalence, risk factors and observations on co-infection with Fasciola hepatica. Parasitology. 2017;144:237-47

9. Kelley JM, Elliott TP, Beddoe T, Anderson G, Skuce P, Spithill TW. Current threat of triclabendazole resistance in Fasciola hepatica. Trends Parasitol. 2016;2(458-469):458-69.

10. Sargison ND. Sustainable helminth control practices in the United Kingdom. Small Rumin Res. 2014;118:35-40.

11. Bennema SC, Ducheyne E, Vercruysse J, Claerebout E, Hendrickx G, Charlier J. Relative importance of management, meteorological and environmental factors in the spatial distribution of Fasciola hepatica in dairy cattle in a temperate climate zone. Int J Parasitol. 2011;41:225-33.

12. Charlier J, Bennema SC, Caron Y, Counotte M, Ducheyne E, Hendrickx G, et al. Towards assessing fine-scale indicators for the spatial transmission risk of Fasciola hepatica in cattle. Geospat Health. 2011;5239:239-45.

13. Howell A, Baylis M, Smith R, Pinchbeck G, Williams D. Epidemiology and impact of Fasciola hepatica exposure in high-yielding dairy herds. Prev Vet Med. 2015;121:41-8.

14. Sargison ND, Scott PR. Diagnosis and economic consequences of triclabendazole resistance in Fasciola hepatica in a sheep flock in south-east Scotland. Vet Rec. 2011;168:159.

15. Ollerenshaw CB, Rowlands WT. A method of forecasting the incidence of fascioliasis in Anglesey. Vet Rec. 1959;71:591-8.

16. Beltrame L, Dunne T, Vineer HR, Walker JG, Morgan ER, Vickerman P, et al. A mechanistic hydro-epidemiological model of liver fluke risk. J R Soc Interface. 2018;15:20180072.

17. Rapsch C, Dahinden T, Heinzmann D, Torgerson PR, Braun U, Deplazes $P$, et al. An interactive map to assess the potential spread of Lymnaea truncatula and the free-living stages of Fasciola hepatica in Switzerland. Vet Parasitol. 2008;154:242-9.

18. De Roeck E, Van Coillie F, De Wulf R, Soenen K, Charlier J, Vercruysse J, et al. Fine-scale mapping of vector habitats using very high resolution satellite imagery: a liver fluke case-study. Geospat Health. 2014;8:S671-83.

19. Rondelaud D, Hourdin P, Vignoles P, Dreyfuss G, Cabaret J. The detection of snail host habitats in liver fluke infected farms by use of plant indicators. Vet Parasitol. 2011;181:166-73.

20. Jones RA, Brophy PM, Davis CN, Davies TE, Emberson H, Stevens PR, et al. Detection of Galba truncatula, Fasciola hepatica and Calicophoron daubneyi environmental DNA within water sources on pasture land, a future tool for fluke control? Parasit Vectors. 2018;11:342.

21. Deng MH, Zhong LY, Kamolnetr O, Limpanont Y, Lv ZY. Detection of helminths by loop-mediated isothermal amplification assay: a review of updated technology and future outlook. Infect Dis Poverty. 2019;8:20.

22. Notomi T, Okayama H, Masubuchi H, Yonekawa T, Watanabe K, Amino N, et al. Loop-mediated isothermal amplification of DNA. Nucleic Acid Res. 2000;28:e63.

23. Tomita N, Mori Y, Kanda H, Notomi T. Loop-mediated isothermal amplification (LAMP) of gene sequences and simple visual detection of products. Nat Protoc. 2008;3:877-82.

24. Nagamine K, Watanabe K, Ohtsuka K, Hase T, Notomi T. Loop-mediated isothermal amplification reaction using a nondenatured template. Clin Chem. 2001;47:1742-3.

25. Goto M, Honda E, Ogura A, Nomoto A, Hanaki Kl. Colorimetric detection of loop-mediated isothermal amplification reaction by using hydroxy naphthol blue. Biotechniques. 2009;46:167-72.

26. Ai L, Li C, Elsheikha HM, Hong SJ, Chen JX, Chen SH, et al. Rapid identification and differentiation of Fasciola hepatica and Fasciola gigantica by a loop-mediated isothermal amplification (LAMP) assay. Vet Parasitol. 2010;74:228-33. 
27. Arifin MI, Höglund J, Novobilský A. Comparison of molecular and conventional methods for the diagnosis of Fasciola hepatica infection in the field. Vet Parasitol. 2016;15:8-11.

28. Nagamine K, Hase T, Notomi T. Accelerated reaction by loop-mediated isothermal amplification using loop primers. Mol Cell Probes. 2002;16:223-9.

29. Kaneko H, Kawana T, Fukushima E, Suzutani T. Tolerance of loop-mediated isothermal amplification to a culture medium and biological substances. J Biochem Biophys Methods. 2007;70:499-501.

30. Macan TT. A key to the British fresh- and brackish-water gastropods, with notes on their ecology. 4th ed. Ambleside: Freshwater Biological Association; 1977.

31. Caron Y, Righi S, Lempereur L, Saegerman C, Losson B. An optimized DNA extraction and multiplex PCR for the detection of Fasciola sp. in lymnaeid snails. Vet Parasitol. 2011;178:93-9.

32. Jones RA, Williams HW, Dalesman S, Ayodeji S, Thomas RK, Brophy PM The prevalence and development of digenean parasites within their intermediate snail host, Galba truncatula, in a geographic area where the presence of Calicophoron daubneyi has recently been confirmed. Vet Parasitol. 2017:240:68-74.

33. Goldberg CS, Turner CR, Deiner K, Klymus KE, Thomsen PF, Murphy MA, et al. Critical considerations for the application of environmental DNA methods to detect aquatic species. Methods Ecol Evol. 2016;7:1299-307.

34. Anthony VJ, Joanne GM. Understanding interobserver agreement: the Kappa statistic. Fam Med. 2005;37:360-3.

35. Le TH, Nguyen NTB, Truong NH, Van De N. Development of mitochondrial loop-mediated isothermal amplification for detection of the small liver fluke Opisthorchis viverrini (Opisthorchiidae; Trematoda; Platyhelminthes). J Clin Microbiol. 2012;50:1178.

36. Martínez-Valladares M, Rojo-Vázquez FA. Loop-mediated isothermal amplification (LAMP) assay for the diagnosis of fasciolosis in sheep and its application under field conditions. Parasit Vectors. 2016;9:73.

37. Cevallos W, Fernández-Soto P, Calvopiña M, Fontecha-Cuenca C, Sugiyama H, Sato M, et al. LAMPhimerus: a novel LAMP assay for detecting Amphimerus sp. DNA in human stool samples. PLoS Negl Trop Dis. 2017:11:e0005672.

38. Arimatsu Y, Kaewkes S, Laha T, Hong SJ, Sripa B. Rapid detection of Opisthorchis viverrini copro-DNA using loop-mediated isothermal amplification (LAMP). Parasitol Int. 2012;61:178-82.

39. Rahman SMM, Song HB, Jin Y, Oh JK, Lim MK, Hong ST, et al. Application of a loop-mediated isothermal amplification (LAMP) assay targeting cox1 gene for the detection of Clonorchis sinensis in human fecal samples. PLoS Negl Trop Dis. 2017;11:e0005995.

40. Cai XQ, Xu MJ, Wang YH, Qiu DY, Liu GX, Lin A, et al. Sensitive and rapid detection of Clonorchis sinensis infection in fish by loop-mediated isothermal amplification (LAMP). Parasitol Res. 2010;106:1379-83.

41. Arimatsu Y, Kaewkes S, Laha T, Sripa B. Specific diagnosis of Opisthorchis viverrini using loop-mediated isothermal amplification (LAMP) targeting parasite microsatellites. Acta Trop. 2015;141:368-71.

42. Deagle BE, Eveson JP, Jarman SN. Quantification of damage in DNA recovered from highly degraded samples—a case study on DNA in faeces. Front Zool. 2006;3:11.

43. Prokopowich CD, Gregory TR, Crease TJ. The correlation between rDNA copy number and genome size in eukaryotes. Genome. 2003;46:48-50.

44. Huver JR, Koprivnikar J, Johnson PTJ, Whyard S. Development and application of an eDNA method to detect and quantify a pathogenic parasite in aquatic ecosystems. Ecol Appl. 2015;25:991-1002.

45. Rathinasamy V, Hosking C, Tran L, Kelley J, Williamson G, Swan J, et al. Development of a multiplex quantitative PCR assay for detection and quantification of DNA from Fasciola hepatica and the intermediate snail host, Austropeplea tomentosa, in water samples. Vet Parasitol. 2018;259:17-24

46. Gandasegui J, Fernández-Soto P, Hernández-Goenaga J, López-Abán J, Vicente B, Muro A. Biompha-LAMP: a new rapid loop-mediated isothermal amplification assay for detecting Schistosoma mansoni in Biomphalaria glabrata snail host. PLoS Negl Trop Dis. 2016;10:e0005225.

47. Hamburger J, Abbasi I, Kariuki C, Wanjala A, Mzungu E, Mungai P, et al. Evaluation of loop-mediated isothermal amplification suitable for molecular monitoring of schistosome-infected snails in field laboratories. Am J Trop Med Hyg. 2013;88:344-51.
48. Chen Y, Wen T, Lai DH, Wen YZ, Wu ZD, Yang TB, et al. Development and evaluation of loop-mediated isothermal amplification (LAMP) for rapid detection of Clonorchis sinensis from its first intermediate hosts, freshwater snails. Parasitology. 2013;140:1377-83.

49. Tebbe CC, Vahjen W. Interference of humic acids and DNA extracted directly from soil in detection and transformation of recombinant DNA from bacteria and a yeast. Appl Environ Microbiol. 1993;59:2657-65.

50. Bakheit MA, Torra D, Palomino LA, Thekisoe OMM, Mbati PA, Ongerth J, et al. Sensitive and specific detection of Cryptosporidium species in PCRnegative samples by loop-mediated isothermal DNA amplification and confirmation of generated LAMP products by sequencing. Vet Parasitol. 2008;158:11-22.

51. Poon LLM, Wong BWY, Ma EHT, Chan KH, Chow LMC, Abeyewickreme $W$, et al. Sensitive and inexpensive molecular test for falciparum malaria: defecting Plasmodium falciparum DNA directly from heat-treated blood by loop-mediated isothermal amplification. Clin Chem. 2006;52:303-6.

52. Kashir J, Yaqinuddin A. Loop mediated isothermal amplification (LAMP) assays as a rapid diagnostic for COVID-19. Med Hypotheses. 2020;141:109786.

53. Martzy R, Kolm C, Brunner K, Mach RL, Krska R, Šinkovec H, et al. A loopmediated isothermal amplification (LAMP) assay for the rapid detection of Enterococcus spp in water. Water Res. 2017;122:62-9.

54. Iwasaki M, Yonekawa T, Otsuka K, Suzuki W, Nagamine K, Hase T, et al. Validation of the loop-mediated isothermal amplification method for single nucleotide polymorphism genotyping with whole blood. Genome Lett. 2006;2:119-26.

55. Gandasegui J, Fernández-Soto P, Carranza-Rodríguez C, Pérez-Arellano JL, Vicente B, López-Abán J, et al. The rapid-heat LAMPellet method: a potential diagnostic method for human urogenital schistosomiasis. PLoS Negl Trop Dis. 2015;9:e0003963.

56. Polley SD, González IJ, Mohamed D, Daly R, Bowers K, Watson J, et al. Clinical evaluation of a loop-mediated amplification kit for diagnosis of imported malaria. J Infect Dis. 2013;208:637-44.

57. Mikita K, Maeda T, Yoshikawa S, Ono T, Miyahira Y, Kawana A. The Direct Boil-LAMP method: a simple and rapid diagnostic method for cutaneous leishmaniasis. Parasitol Int. 2014;63:785-9.

58. Reyes JCB, Solon JAA, Rivera WL. Development of a loop-mediated isothermal amplification assay for detection of Trichomonas vaginalis. Diagn Microbiol Infect Dis. 2014;79:337-41.

59. Mori Y, Notomi T. Loop-mediated isothermal amplification (LAMP): a rapid, accurate, and cost-effective diagnostic method for infectious diseases. J Infect Chemother. 2009;15:62-9.

60. Perera RS, Ding XC, Tully F, Oliver J, Bright N, Bell D, et al. Development and clinical performance of high throughput loop-mediated isothermal amplification for detection of malaria. PLoS One. 2017;12:e0171126.

61. Bearinger JP, Dugan LC, Baker BR, Hall SB, Ebert K, Mioulet V, et al. Development and initial results of a low cost, disposable, point-of-care testing device for pathogen detection. IEEE Trans Biomed Eng. 2011;58:805-8.

\section{Publisher's Note}

Springer Nature remains neutral with regard to jurisdictional claims in published maps and institutional affiliations.

Ready to submit your research? Choose BMC and benefit from:

- fast, convenient online submission

- thorough peer review by experienced researchers in your field

- rapid publication on acceptance

- support for research data, including large and complex data types

- gold Open Access which fosters wider collaboration and increased citations

- maximum visibility for your research: over $100 \mathrm{M}$ website views per year

At $\mathrm{BMC}$, research is always in progress.

Learn more biomedcentral.com/submissions 